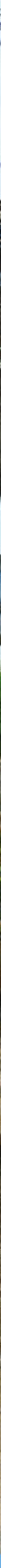

\title{
Mapping the potential (quickscan) for salt and drought tolerant crops and cropping systems in the Mekong Delta
}

Jan Verhagen, Greet Blom-Zandstra, Nguyen Duc Xuan Chuong, Nguyen Thị Viet Ha, Peter Prins,

Gerard van der Linden

WAGENINGEN

UNIVERSITY \& RESEARCH 



\section{Mapping the potential (quickscan) for salt and drought tolerant crops and cropping systems in the Mekong Delta}

Jan Verhagen ${ }^{1}$, Greet Blom-Zandstra ${ }^{1}$, Nguyen Duc Xuan Chuong ${ }^{2}$, Nguyen Thị Viet $\mathrm{Ha}^{3}$, Peter Prins ${ }^{4}$,

Gerard van der Linden ${ }^{1}$

1 Wageningen University \& Research

2 Nong Lam University, Faculty of Agronomy, Department of Industrial Crops, Ho Chi Minh City, Vietnam

3 Vietnam Farmers' Union

4 Land, Water and Food Consult

This study was carried out by the Wageningen Research Foundation (WR) business unit Agrosystems Research and was commissioned and financed by the by Rijksdienst voor Ondernemend Nederland in the context of the Policy Support. Project title: Mapping the potential (quickscan) for salt and drought tolerant crops and cropping systems in the Mekong Delta (MAT16VN06).

WR is part of Wageningen University \& Research, the collaboration of Wageningen University and Wageningen Research Foundation.

Wageningen, October 2017

Report WPR-716 
Verhagen, Jan, Greet Blom-Zandstra, Nguyen Duc Xuan Chuong, Nguyen Thị Viet Ha, Peter Prins, Gerard van der Linden, 2017. Mapping the potential (quickscan) for salt and drought tolerant crops and cropping systems in the Mekong Delta. Wageningen Research, Report WPR-716. 16 pp.

This report can be downloaded for free at https://doi.org/10.18174/425354

(C) 2017 Wageningen, Stichting Wageningen Research, Wageningen Plant Research, Business Unit Agrosystems Research, P.O. Box 16, 6700 AA Wageningen, The Netherlands; T +31 (0)317 480700 ; www.wur.eu/plant-research

Chamber of Commerce no. 09098104 at Arnhem

VAT NL no. 8065.11.618.B01

Stichting Wageningen Research. All rights reserved. No part of this publication may be reproduced, stored in an automated database, or transmitted, in any form or by any means, whether electronically, mechanically, through photocopying, recording or otherwise, without the prior written consent of the Stichting Wageningen Research.

Stichting Wageningen Research is not liable for any adverse consequences resulting from the use of data from this publication.

Report WPR-716

Photo cover: Shutterstock 


\section{Contents}

1

Salt and drought tolerant crops and cropping systems in the Mekong Delta

5

1.1 A quickscan of selected crops for the Mekong river delta

1.2 Network

6

1.3 Outreach

6

1.4 Foci for the pilot studies

Annex 1 Overview of the selected crops

Annex 2 Outreach 10

Annex 3 Schedule mission WUR Salinization Vietnam 



\section{$1 \quad$ Salt and drought tolerant crops and cropping systems in the Mekong Delta}

Vietnam is one of the most vulnerable countries to the impacts of climate change. It's extensive lowland coastal areas which support most of the country's agriculture and aquaculture production, is particularly susceptible to flooding and saline intrusion. Both sea level rise and land subsidence are slowly increasing the risks of salinization of the coastal lowlands. In addition, drought, as experienced during the 2015-2016 El Niño Southern Oscillation (ENSO) phenomenon, will not only enhance saline intrusion but drought also has direct implications for production systems.

On 15 March 2016, the Vietnamese government and the United Nations Development Programme (UNDP) organized a meeting with donors, international organizations and other partners to discuss joint efforts for drought response and recovery. Another meeting was presided by the Ministry of Agriculture and Rural Development (MARD) Minister Cao Duc Phat and the UN Resident Coordinator on 30 March 2016 to report on the recent rapid assessments of current natural hazards and call for immediate, medium- and long-term support from the international community. MARD recognizes that this crisis and its subsequent effects (e.g. inundation after the drought) will recur in the future, and that there is a need to prepare and plan for necessary response measures. Herewith started the process, that resulted in the commissioning and financing of this quick scan by the Rijksdienst voor Ondernemend Nederland. The quick scan is the key output of the project 'Mapping the potential (quickscan) for salt and drought tolerant crops and cropping systems in the Mekong Delta' (RVO project: MAT16VN06). with the purpose to develop a sustainable climate smart agriculture in the Mekong Delta to secure food and income of farmers by providing them knowledge and information to respond to salt and drought stress in agriculture.

This study will provide input in this discussion and provide strategies to deal with the urgent and immediate needs while looking a medium and long strategies to deal with saline and drought conditions. A key outcome of the project is a network with the national farmers' union (VNFU), local universities (Nong Lam University and Can Tho University), dutch private sector (east west seed, de Heus, and Land Water and Food Consult) and Wageningen UR.

The core of the work is a flora in which based on a literature review and interviews with local and international experts a quick scan of current and promising crops, in total 29 species, and cropping system level strategies to respond to stress circumstances in agriculture is presented.

A short (5 day) mission to the Mekong delta was organised in which the farmers' Union, Land Water and Food Consult, Nong Lam University and Wageningen UR joined to reflect on local issues in Bac Lieu, Hau Giang and Long An and identified possible interventions focussing on crops and cropping systems. Understand the issues and cross check the flora and identify foci for short and medium-term interventions (pilots) with a long-term outlook that can assist farmers in dealing with changing environmental conditions and provide ways to secure and enhance incomes. These key outcomes are summarized in this note.

\subsection{A quickscan of selected crops for the Mekong river delta}

Vietnam is one of the most vulnerable countries to the impacts of climate change. It's extensive lowland coastal areas which support most of the country's agriculture and aquaculture production, is particularly susceptible to flooding and saline intrusion. The government realizes that there is an urgent need to prepare and plan for necessary response measures. Therefore, a quick scan focussing on the Mekong River Delta, using international and local expertise with the aim to identify promising crop and cropping system level strategies to address salt and drought stress. Moreover, acidity and humidity stress is also addressed.

Based on a literature review and interviews with local and international experts, the quick scan maps current and promising crops, in total 29 species, and cropping system level strategies to respond to stress circumstances in agriculture. For each crop, a short 1 page information sheet is created with 
Latin name, vernacular names, drought sensitivity, salinity sensitivity, thresholds and recognizing stress, current tillage, management practices and recommendations (see Annex 1 and report WPR-688).

\subsection{Network}

A network including the farmer communities, research and the private sector was established. The network includes: Viet Nam Farmer's Union, Nong Lam University; Land and Wageningen UR, Water \& Food Consult; East-West Seed and de Heus. Working with farmers' is not a given for most research institutes and universities, this project has contributed to building these ties. Connecting and understanding the needs and of the local farmer communities and private sector is crucial to guide research and create impact. Part of listening to farmers needs is understanding the role of women, which needs to be reflected in the pilot studies.

\subsection{Outreach}

During the project period (January - July 2017) several publications to draw attention to the work were made see Annex 2. Also, here the network has been able to highlight the importance of a joined agenda and create a cooperative spirit.

\subsection{Foci for the pilot studies}

Studies on the problems on drought and salinity in relation to climate change for the Mekong River Delta are numerous. Triggered by the 2015-2016 el Nino event much needed plans are being developed and old plans are revisited. Most of these plans are high level which eventually have to materialize on the ground. This note aims to define actions for farmers, local government, the private sector and research to learn and design innovative practical farm level responses to threats of drought and salinity.

Strategies to diversify away from the rice monoculture and increase farmers' income go back decades. These strategies included the inclusion of shrimp and fish in the rotation or allocating part of the land to vegetable production. From the discussions with local farmers' organizations several aspects related to this transition emerged. The local experiences and problems addressed were not new, but recent droughts have aggravated the issues and increased the sense of urgency. For commodities to be attractive for farmers a market pull is needed the right to deliver depends on the ability to compete on quality and price. Both are strongly related to the distance to markets this is especially important for perishables.

Water and soil management are important for successful crop production in any delta and requires regional coordination. Water has, justly, been a key focus of many interventions in the delta. Farmers are linked to the regional platforms but interventions are often outside the scope of local farmers. With this biased focus, on-farm interventions are often not worked out. Soil management has focused on acid sulfate soils and more specifically on water management needed for these soils. Important farm level management activities as tillage, nutrient management and crop protection did not receive the same level of attention, clear guidance for farmers is lacking. The pilots will focus on short and medium term actions related to crops and cropping systems that can be explored with the local farmer and science communities. The pilots will address irrigation techniques when appropriate, for example drip irrigation is an option in high value crops. Water quality and energy (diesel) costs are the main issues.

Ongoing changes occurring in the delta are the inclusion of shrimp, a dry season vegetable or maize in the crop rotation or a complete transition to other systems such as shrimp, citrus or dragon fruit. The latter strategy results in a lock-in with a market oriented monoculture. Some research groups are experimenting with new or less know crops such as Aloe vera and Quinoa. Quinoa is stress tolerant and field experimentation is needed. 
The pilots will be worked out in more detail with local partners. For dragon fruit a MoU is being prepared to address all aspects of the value chain.

The identified foci are:

\section{Crop information}

Information provision to farmers on performance and stress tolerance levels for different crops and crop varieties can be improved. Science is working on new varieties linking to farmers at an early stage will improve the adoption rates by farmers. The flora is a first step in providing such information.

\section{Soil services}

Establishing services to provide farmers with the much needed soil fertility status and fertilizer recommendations. For all crop based systems information on soil and nutrient management is lacking, there is no clear service to check the soil fertility or provide fertilizer recommendations.

\section{Vegetables}

Near urban centers, vegetables are an interesting dry season cash crop. Experimenting with salt tolerant vegetables in controlled experimental fields and on farm will provide farmers with clear particle knowledge on the cultivation of these crops. East West Seed is willing to collaborate.

\section{Maize}

With the increasing consumption of animal protein the need for animal feed like maize is increasing. Maize is a well studies crop and can tolerate some levels of salinity, it will tolerate drought.

De Heus animal nutrition, with an office in Vietnam is already looking at regions suitable for maize production. Farmers have experience with maize but growing it at scale and delivering quality requires upgrading of the skills and improving the information flow to the farmers.

\section{Quinoa}

Is a relative new crop for the region, it is a high quality crop that can tolerate saline and dry conditions. Moving from experimental fields at research facilities to on-farm experimentation is the next step.

\section{Dragon fruit}

Experiences with dragon fruit are scattered and the Vietnamese farmers union (VNFU) started an initiative to improve the production, product quality and value chain logistics for this crop. VNFU with importers to the European market and research are looking for ways to start a program on dragon fruit.

\section{Rice}

Rice is a key crop in the Mekong river delta and experiments with salt tolerant rice are already conducted. Wageningen UR is involved with research on salt tolerance and will with Nong Lam University collaborate and explore funding and training opportunities. Most pilot studies will include rice, so also longer term effects related to the cropping system are important. Soil structure in paddy rice systems is known to be less favorable for e.g. vegetables.

\section{Shrimp}

A commonly found combination in saline areas is rice during the wet season with shrimp in the dry period. Because of the clear market pull shrimp is very attractive for farmers. Sourcing feed is a and controlling disease are key concerns. 


\section{Annex 1 Overview of the selected crops}

\section{A flora of agricultural and horticultural crops}

\section{A quick scan of selected crops in the Mekong Delta}

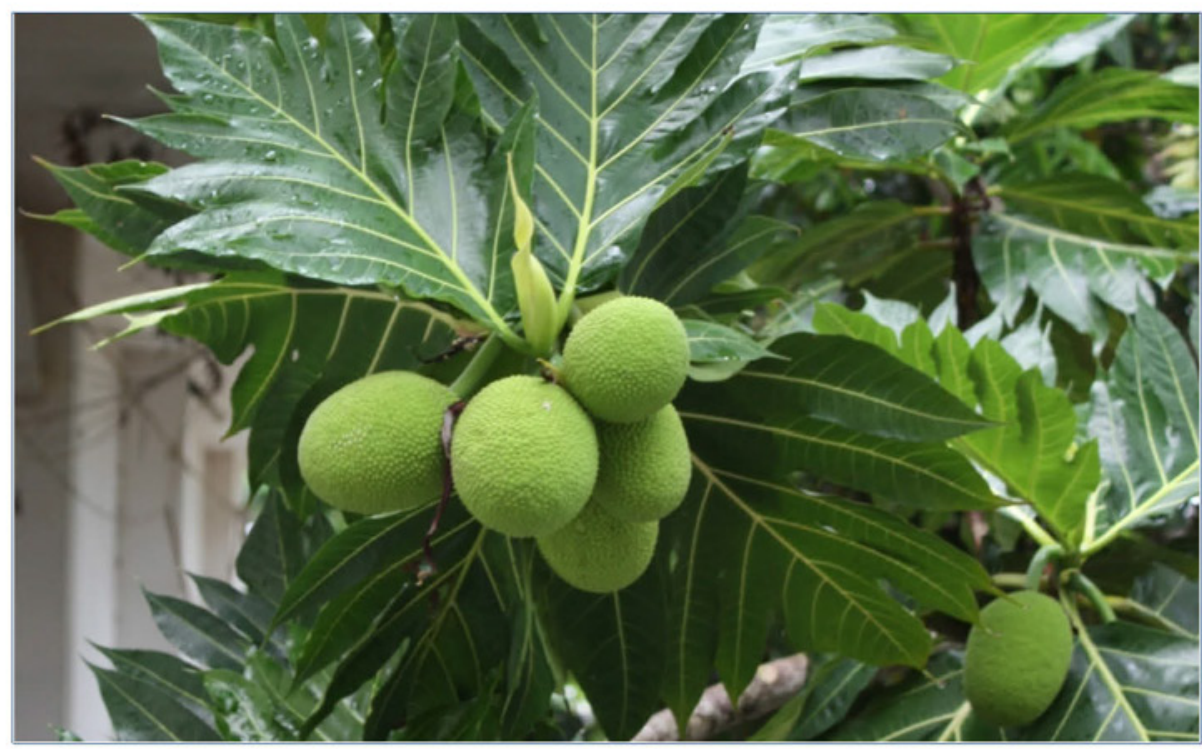

Greet Blom-Zandstra', Martina Nardelli?, Nguyen Duc Xuan Chuong ${ }^{3}$, Vu Thi Thu Hien', Nguyen Bao Quoc., Nguyen Thị Viet $\mathrm{Ha}^{6}$, Gerard van der Linden', Jan Verhagen ${ }^{1}$

1 Wageningen University \& Research

${ }^{2}$ University of Turin, Department of Agricultural, Forest and Food Sciences

${ }^{3}$ Nong Lam University, Faculty of Agronomy, Department of Industrial Crops, Ho Ch Minh aty, Vetnam

"Genetic Engineering Division Agricultural Genetics Institute (AGI) Pham Van Dong street, Tuliem, Hanoi, Metnam

5 Nong Lam University, Research Institute for Biotechnology and Environment, Ho Chu Minh Cty, Vietnam

'Vietnam Farmers' Union

This study was carried out by the Wageningen Research Foundation (WR) Agrosystems Research and was commissioned and financed by Rijksdienst voor Ondernemend Nederland in the context of the Policy Support. Project title: Mapping the potential (quickscan) for salt and drought tolerant crops and cropping systems in the Mekong Delta (MAT16VNO6).

WR is part of Wageningen University \& Research, the collaboration of Wageningen University and Wageningen Research Foundation. 


\section{Summary table}

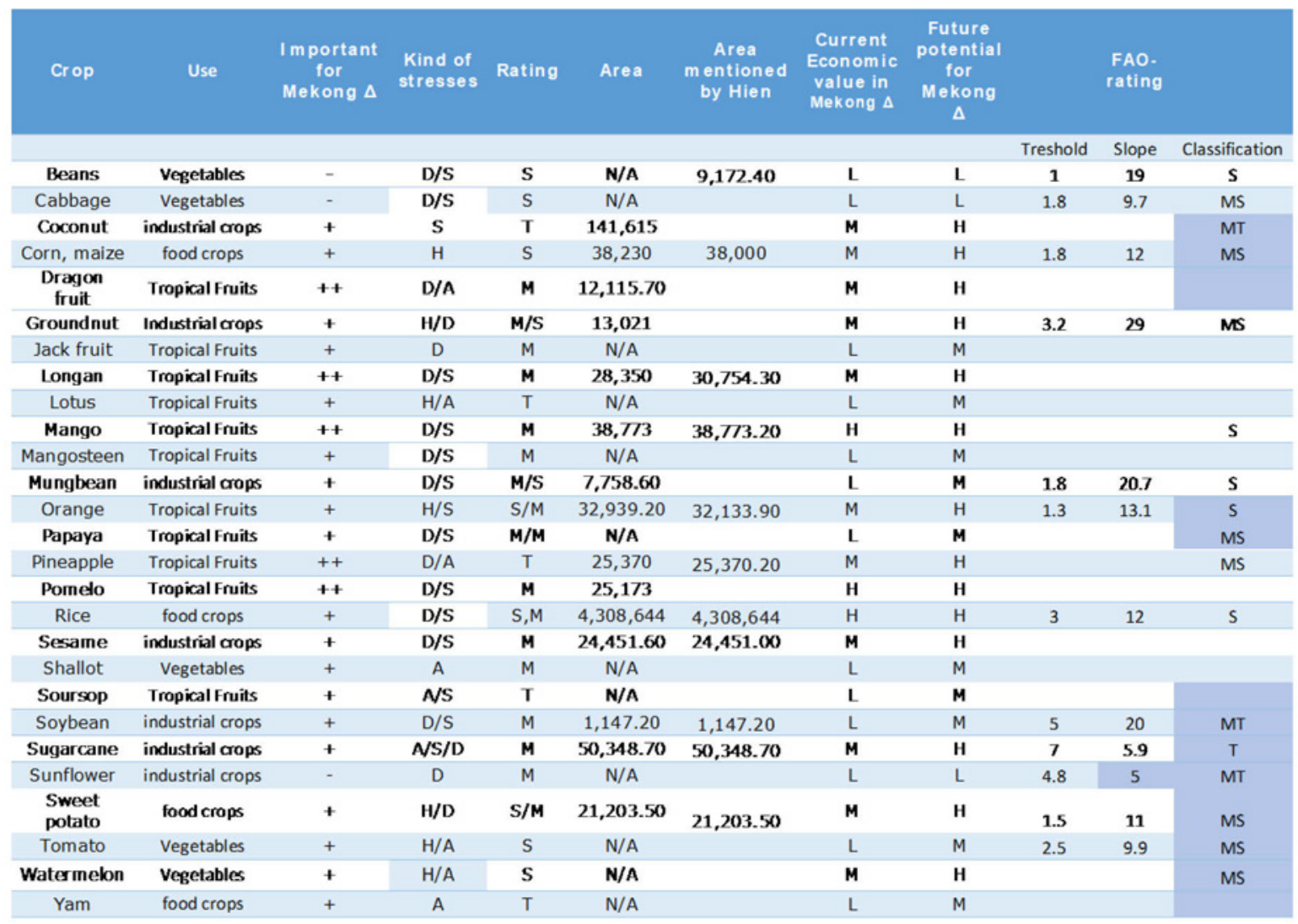

\begin{tabular}{lll} 
Legend & A & Acidity \\
\hline Kind of stresses & D & Drought \\
\hline & H & Humidity \\
\hline & S & Salinity \\
\hline Rating & T & Tolerant \\
\hline & M & Moderately tolerant \\
\hline Economic value & S & Sensitive \\
\hline & L & Low \\
\hline Area & M & Medium \\
\hline & H & High \\
\hline
\end{tabular}




\section{Annex 2 Outreach}

- http://vietnamfarmerunion.vn/sitepages/news/1084/52772/vnfu-is-in-collaboration-withnetherlands-to-improve-the-life-of-farmers-at-drought-and-salinization-areas

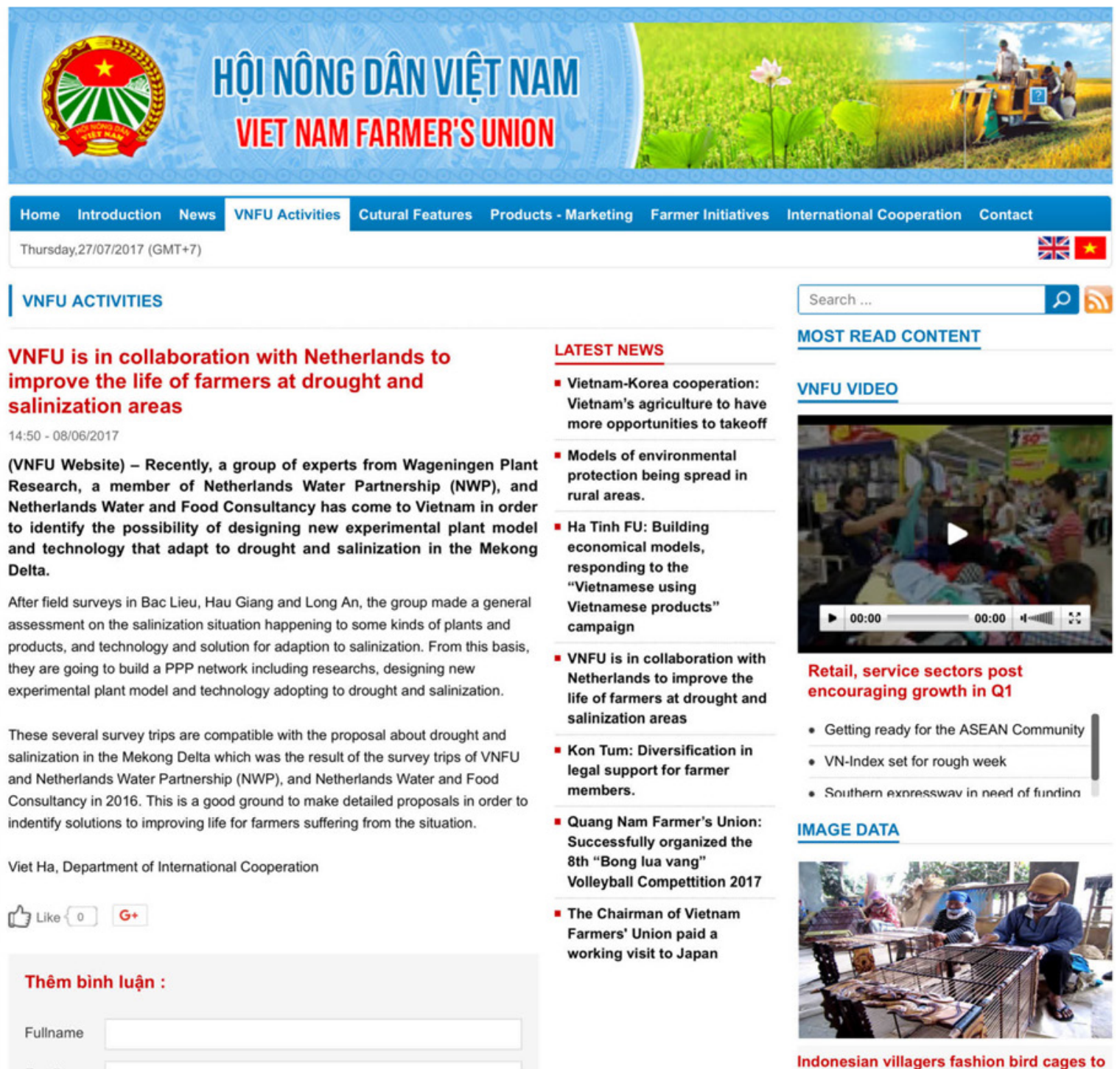

Email

Comment

Comment

LATEST NEWS
- Vietnam-Korea cooperation:
Vietnam's agriculture to have
more opportunities to takeoff
- Models of environmental
protection being spread in
rural areas.
- Ha Tinh FU: Building
economical models,
responding to the
"Vietnamese using
Vietnamese products"
campaign
- VNFU is in collaboration with
Netherlands to improve the
life of farmers at drought and
salinization areas
- Kon Tum: Diversification in
legal support for farmer
members.
- Quang Nam Farmer's Union:
Successfully organized the
8 th "Bong lua vang"
Volleyball Compettition 2017
- The Chairman of Vietnam
Farmers' Union paid a
working visit to Japan

Indonesian villagers fashion bird cages to furnish income

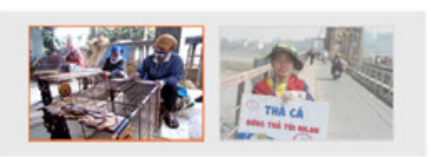

Tin tức liên quan :
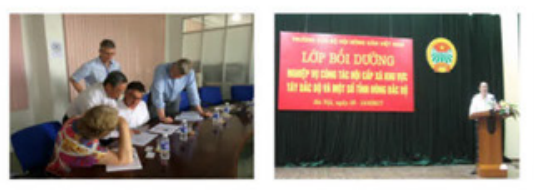

[2]

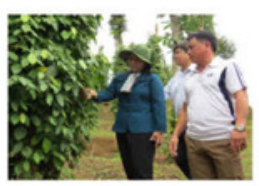


- http://vietnamfarmerunion.vn/sitepages/news/1084/52296/wageningen-plant-research-wur-visitedsome-provinces-in-mekong-delta

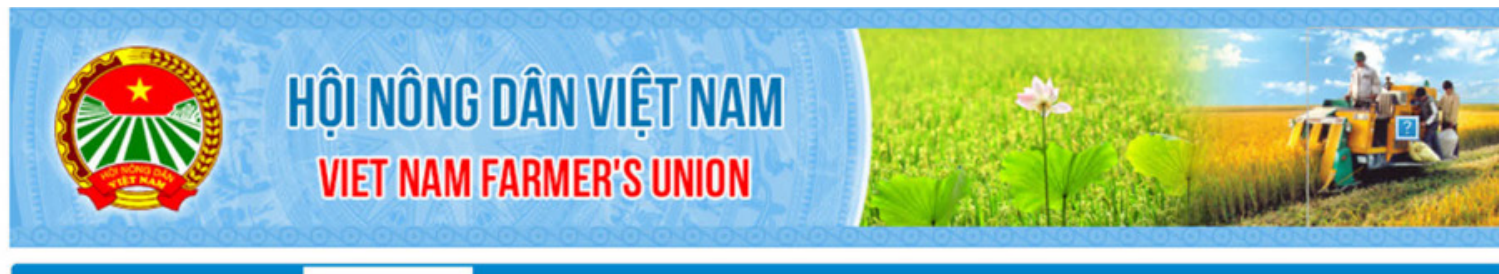

Home Introduction News VNFU Activities Cutural Features Products-Marketing Farmer Initiatives International Cooperation Contact

Thursday,27/07/2017 (GMT+7)

猌匹

| VNFU ACTIVITIES

Wageningen Plant Research (WUR) visited some provinces in Mekong Delta

12:56 - 31/05/2017

From 27 May to 3 June 2017, one 4 person delegation from Wageningen Plant Research (WUR) and the Land Water Food Consult Company visited Vietnam to identify the opportunities for salt and drought tolerant crops in the Mekong area. One researcher from the Nong Lam University in Ho Chi Minh City participated in the team.

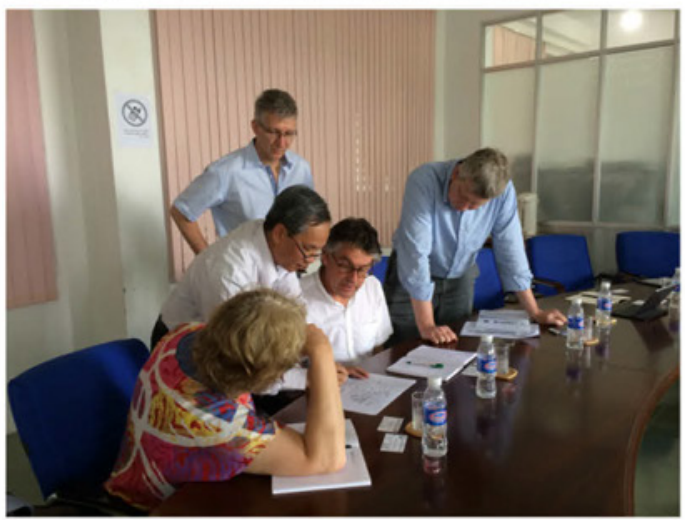

After the trip, a flora with an overview of crops and crop groups with their tolerance levels to drought and saline conditions, alist of promising technologies and field level strategies developed and thus, to set up a network linking private sector and research as well as set-up of a pilot and commitment by local farmers to participate in the elaboration.

Some crops like rice, maize, aloe vera, and some other fruits were considered by stakeholders. However, how to sell agro-product after converting is one of the needs from farmers. Thus, doing reaserch on finding out the salt and drought tolerant crops linked with developing the value chain also should be considered.

This survey fits very well in the outline of the program on salinization in the Mekong as developed during fruitful missions in 2016 organized by VNFU, NWP and Land Water Food Consult Company.

The framework could be base for an ambitious proposal to tackle the impact of salinization. The mission contributed to finding the solutions and intervention to improve the prosperity and livelihood of the farmers, which are prone to salinity and drought in the Mekong detal system.
LATEST NEWS

- Vietnam-Korea cooperation: Vietnam's agriculture to have more opportunities to takeof

Models of environmenta protection being spread in rural areas.

- Ha Tinh FU: Building economical models,

responding to the

responding to the
"Vietnamese using

Vietnamese products"

campaign

- VNFU is in collaboration with Netherlands to improve the life of farmers at drought and salinization areas

- Kon Tum: Diversification in legal support for farmer members.

- Quang Nam Farmer's Union: Successfully organized the 8 th "Bong lua vang" Volleyball Compettition 2017

- The Chairman of Vietnam Farmers' Union paid a working visit to Japan

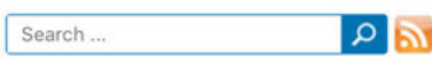

\section{MOST READ CONTENT}

VNFU VIDEO

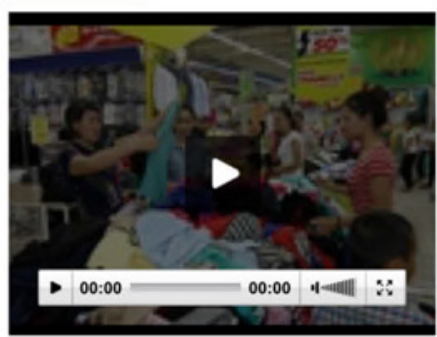

Retail, service sectors post encouraging growth in Q1

- Getting ready for the ASEAN Community

- VN-Index set for rough week

- Southern exnresswav in neerd of fundino

IMAGE DATA

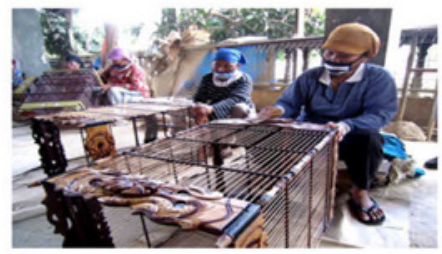

Indonesian villagers fashion bird cages to furnish income

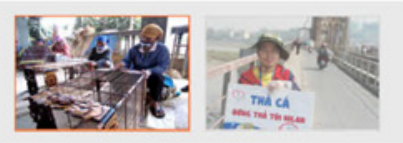

By Viet Ha 
- http://www.agroberichtenbuitenland.nl/vietnam/vietnam-krijgt-steun-nederland-tegen-verzilting/

- http://bit.ly/2sOv7Ss

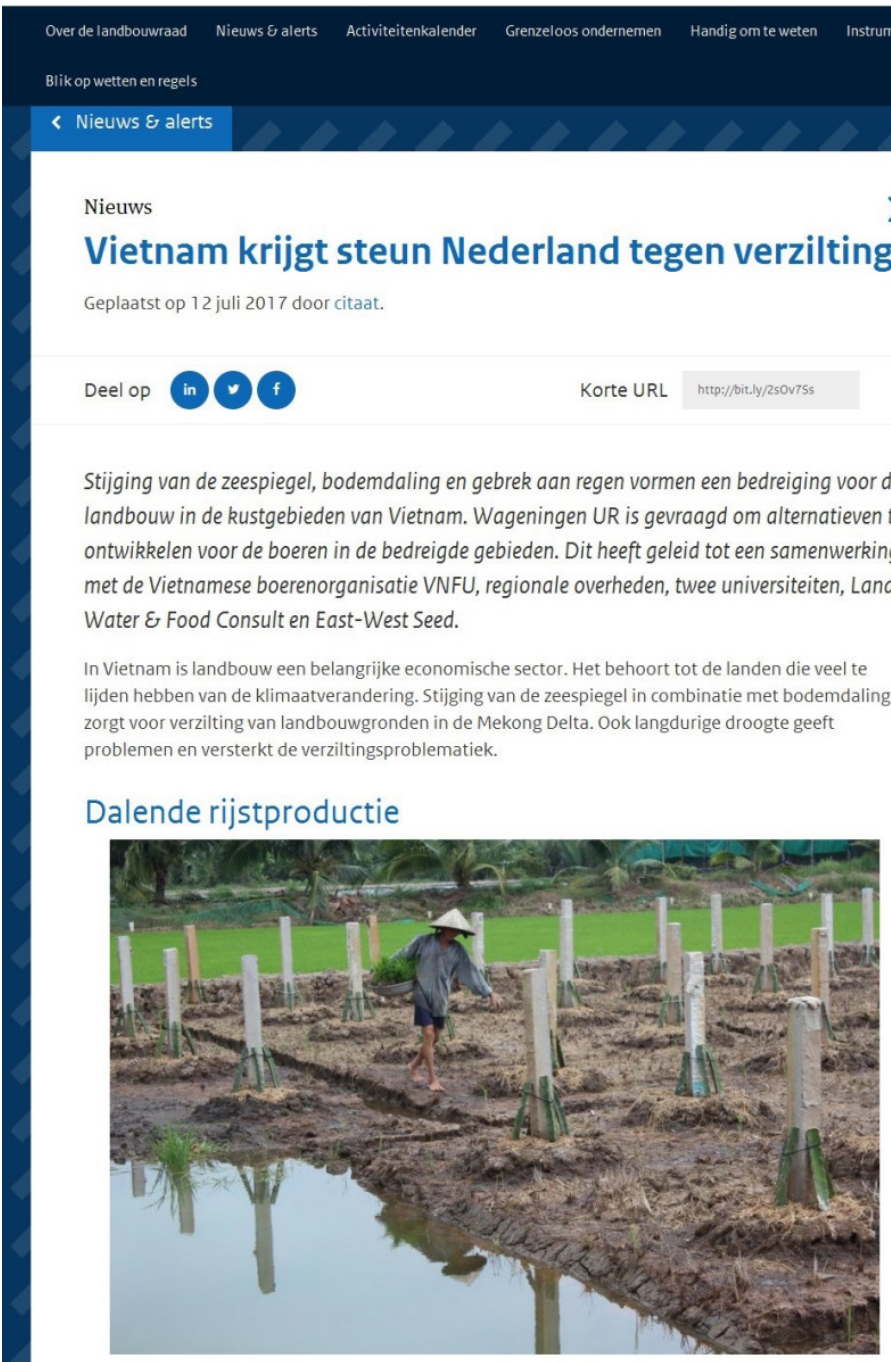

Door verlies aan landbouwgrond daalt de rijstproductie. Dit kan op middellange termijn de voedselvoorziening van de Vietnamese bevolking in gevaar brengen. Het inkomen van de gedupeerde boeren staat onder druk. Dat kan leiden tot een leegloop van het platteland als er geen alternatieven komen voor de rijsttelers.

De Mekong Delta heeft een oppervlakte van bijna 40.000 ha. Er wonen 17,5 miljoen mensen. De landbouw heeft 2.6 miljoen ha in gebruik. Het gebied is verantwoordelijk voor $50 \%$ van de voedselproductie in Vietnam. Rijst is tot nu toe verreweg het belangrijkste gewas.

De Vietnamese landbouwminister Cao Duc Phat riep de internationale gemeenschap in maart 2016 op om het land hulp te bieden bij de zoektocht naar alternatieven voor de boeren in de delta. Inmiddels zijn - mede op initiatief van landbouwraad Arie Veldhuizen - afspraken gemaakt over samenwerking om deze problematiek aan te pakken.

\section{Aanleg van dammen}

Volgens projectleider Jan Verhagen van Wageningen Plant Research - hij is al jaren actief op het terrein van landbouw en klimaatverandering - is al geruime tijd sprake van verzilting in het kustgebied. Klimaatverandering, maar ook aanleg van dammen en ontbossing, verergeren de problematiek. "Vietnam is wat dit betreft niet uniek. Soortgelijke ontwikkelingen zien we ook in kustgebieden van Indonesië, Thailand en bijvoorbeeld Myanmar. Ook daar is Wageningen actief."

\section{Boeren zoeken alternatieven}

Inmiddels kan door de verdroging en verzilting in een deel van de Vietnamese delta niet meer continu rijst worden geproduceerd. Boeren zijn naarstig op zoek naar alternatieven voor het wegvallen van een deel van hun inkomen. Verhagen: "In de praktijk zie je dat boeren experimenteren met groenteen fruitproductie en ook viskweek. Er zijin boeren die. voorzichtig beginnen met de teelt van dragonfruit. Vanwege de omvang van het probleem is het belangrijk om alternatieven te zoeken die structureel een bijdrage leveren aan de voedselzekerheid in het land en de bestaanszekerheid van de boeren."

Het Nederlands-Vietnamese landbouwproject is nog maar net gestart. Deze zomer wordt een plan van aanpak geschreven. De bedoeling is dat vervolgens een aantal pilots wordt uitgevoerd, zowel op proefboerderijen van de betrokken universiteiten als op boerenbedrijven in de Delta. Daarbij wordt gekeken naar het effect van technische ingrepen zoals irrigatie. De nadruk ligt echter op het uittesten van alternatieve teelten, bijvoorbeeld fruit en mais.

\section{Nederlandse bedrijven haken aan}

Het zaadbedrijf East-West Seed en veevoerproducent De Heus zijn inmiddels betrokken bij het project. Verhagen: "Sommige rassen van een bepaald groentegewas kunnen veel beter tegen verzilting dan andere. East-West kan hulp bieden bij de zoektocht naar het juiste ras op de juiste locatie. Mogelijk biedt mais een alternatief in het droge seizoen voor de rijsttelers. De Heus kan die mais vervolgens verwerken in zijn veevoeders. Beide bedrijven zijn al jarenlang actief in Vietnam en zijn dus goed op de hoogte van de lokale productieomstandigheden, kennis van de boeren en de afzetkansen."

\section{Samenwerking staat centraal}

Er is nadrukkelijk sprake van een samenwerkingsproject. De boerenorganisatie VNFU is een van de betrokken partijen. De organisatie denkt mee over de opzet van het onderzoek, maar is later ook van groot belang voor de implementatie van de onderzoeksresultaten. Hetzelfde geldt voor twee universiteiten en

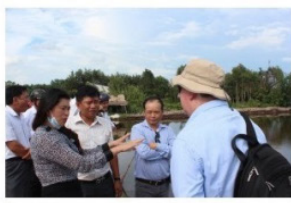
drie provinciale overheden.

Onlangs is een groep Wageningse onderzoekers samen met consultant Peter Prins van Land, Water $\varepsilon$ Food Consult in Vietnam op bezoek geweest om de lokale situatie in ogenschouw te nemen. Prins ondersteunt de Vietnamese boerenbond op het thema water.

Met vertegenwoordigers van de Vietnamese partners, boeren en marktpartijen zijn gesprekken gevoerd. Projectleider Verhagen is hoopvol teruggekeerd uit Vietnam. "Het gevoel van urgentie is bij alle partijen enorm groot. De partijen hebben vertrouwen in elkaar en dat is altijd de basis voor toekomstig succes." 
- Banner presented on July 7, during the visit of Prime Minister Nguyen Xuan Phuc to Wageningen UR.

MỞ RA NHIÈU HƯỚNG ĐI GIÚP ỨNG

PHÓ TİNH HİNH NGẠP MẠN VÀ HẠN

HÁN TẠI ĐÒNG BÀNG SÔNG CỬU LONG

EXPLORING OPTIONS TO RESPOND TO SALINITY

AND DROUGHT IN THE MEKONG RIVER DELTA.

1. Collect information on crops with a focus on salt and drought tolerance and identify field level technologies and strategies to deal with salinity and drought.

2. Try to find out what works via on and off farm experiments testing crops and response strategies.

3. Scale up successful strategies via farmer and private sector networks.

The key to this project is the cooperation between farmers, research and

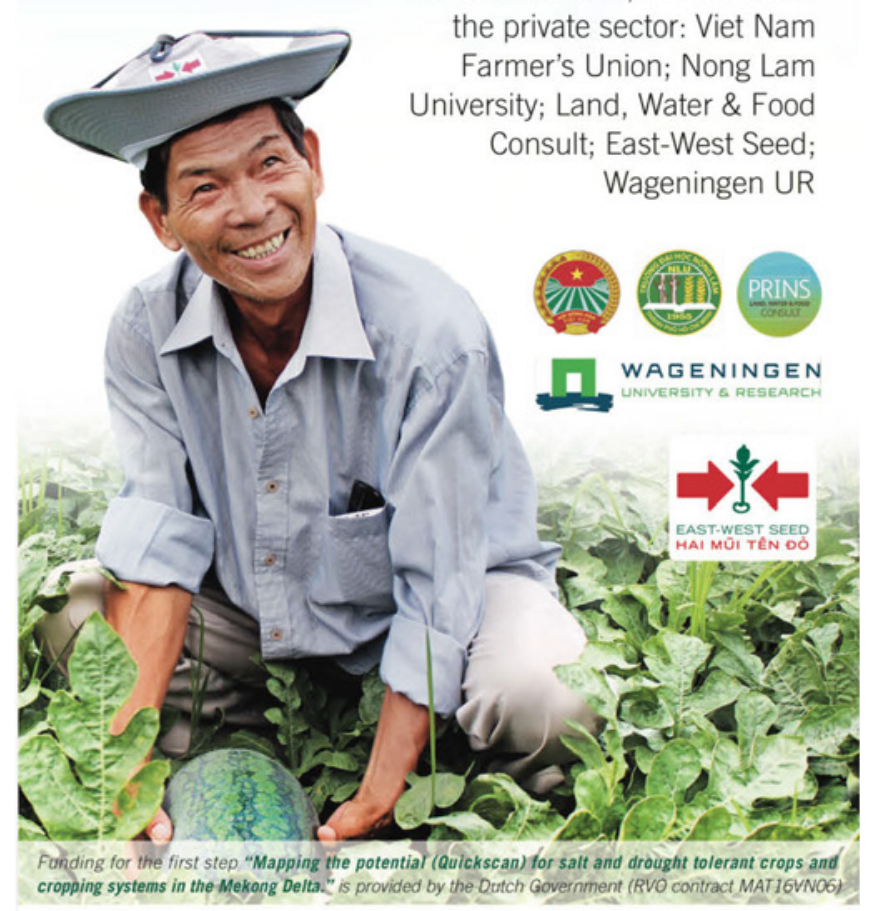

BETTER SEEDS for BETTER YIELD

Y intercomvenswestseod

f

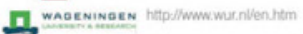

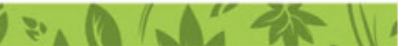




\section{Annex 3 Schedule mission WUR Salinization Vietnam}

\section{Part I.}

May 27

Arrival at HCMC Int. Airport.

May 28

Land Water and Food (Peter Prins) had meetings with:

- Vietnam Farmers' Union (VNFU)

- Tropical Agricultural Research and Consultancy Center in Ho Chi Minh City (TARCC)

Team meeting:

VNFU: Nguyen Thi Viet $\mathrm{Ha}$

LWF: Peter Prins

Wageningen UR: Greet Blom-Zandstra, Gerard van der Linden, Jan Verhagen

May 29

Meetings:

- De Heus Animal Feed (Mr. Gabor Fluit)

- East West Seeds (Joost van Elzakker, Nien Dang Van, Van Thi)

- Nong Lam University (Nguyen Duc Xuan Chuong, Nguyen Bao Quoc)

Nguyen Duc Xuan Chuong joined the field trip

\section{Part II.}

May 30

Meeting

- Farmers' Union (FU) Long An

- Field Visit hosted by FU

- Can Tho University

May 31

- Farmers' Union Bac Lieu

- Provincial People's Committee, Bac Lieu

- Department of Agriculture and Rural Development, Bac Lieu

June 1

Farmers' Union Hau Giang

Field Visit hosted by FU Hau Giang

Meeting with Provincial People's Committee Hau Giang

Visit Can Tho University (CTU)

June 2

- Provincial People's Committee, Vinh Long

- Department of Agriculture and Rural Development, Vinh Long

June 3

- Departure to AMS 
Corresponding address for this report:

P.O. Box 16

6700 AA Wageningen

The Netherlands

T +31 (0)317480700

www.wur.eu/plant-research

Report WPR-716
The mission of Wageningen University and Research is "To explore the potential of nature to improve the quality of life". Under the banner Wageningen University \& Research, Wageningen University and the specialised research institutes of the Wageningen Research Foundation have joined forces in contributing to finding solutions to important questions in the domain of healthy food and living environment. With its roughly 30 branches, 5,000 employees and 10,000 students, Wageningen University \& Research is one of the leading organisations in its domain. The unique Wageningen approach lies in its integrated approach to issues and the collaboration between different disciplines. 



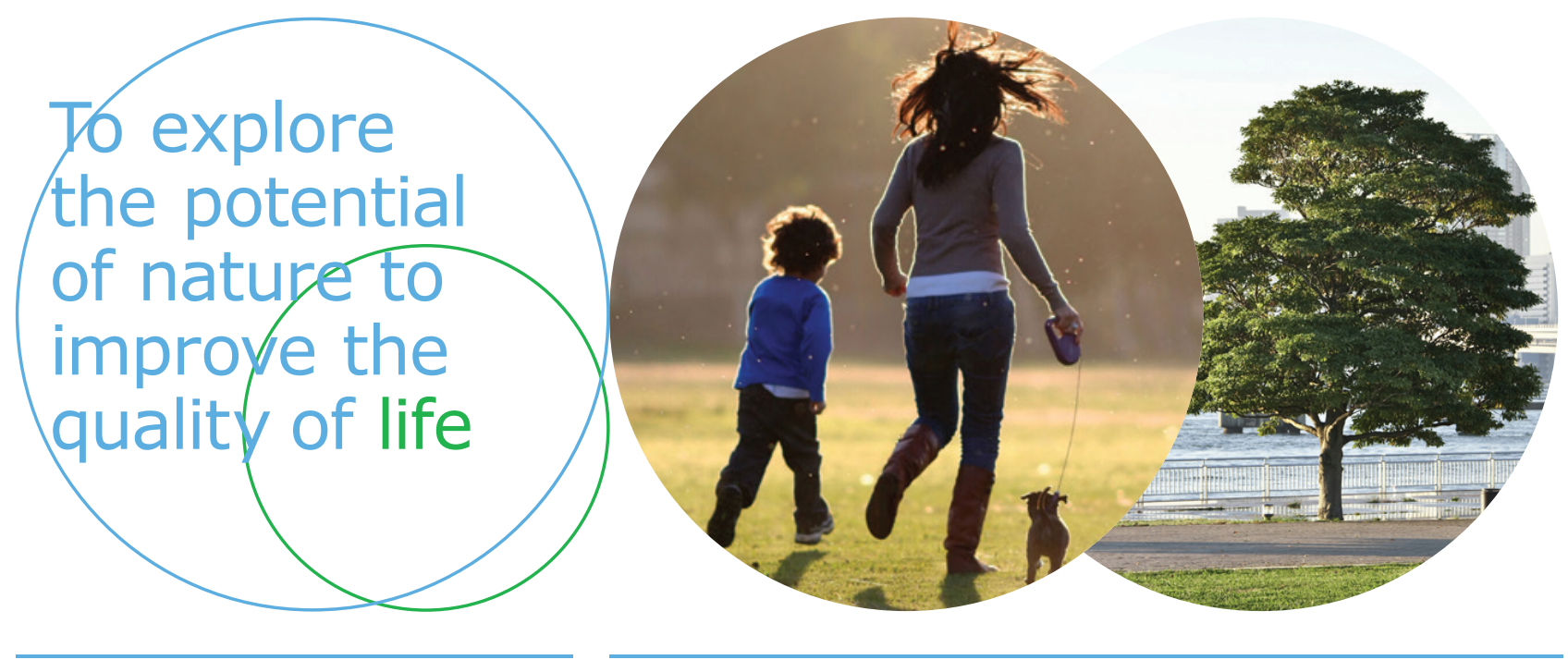

Corresponding address for this report:

P.O. Box 16

6700 AA Wageningen

The Netherlands

T +31 (0)317480700

www.wur.eu/plant-research

Report 716
The mission of Wageningen University and Researb is "To explore the potential of nature to improve the quality of life". Under the banner Wageningen University \& Researb , Wageningen University and the spec alised researb institutes of the Wageningen Researb Foundation have joined fore $s$ in 0 ntributing to inding solutions to important questions in the domain of healthy food and living environment. With its roughly 30 branb es, 5,000 employees and 10,000 students, Wageningen University \& Researb is one of the leading organisations in its domain. The unique Wageningen approab lies in its integrated approab to issues and the collaboration between different disciplines. 